\title{
Record high peaks in PCB concentrations in the Arctic atmosphere due to long-range transport of biomass burning emissions
}

\author{
S. Eckhardt ${ }^{1}$, K. Breivik ${ }^{1,2}$, S. Man ${ }^{1}$, and A. Stohl ${ }^{1}$ \\ ${ }^{1}$ Norwegian Institute for Air Research, Kjeller, Norway \\ ${ }^{2}$ University of Oslo, Department for Chemistry, Oslo, Norway \\ Received: 5 April 2007 - Published in Atmos. Chem. Phys. Discuss.: 10 May 2007 \\ Revised: 14 August 2007 - Accepted: 30 August 2007 - Published: 31 August 2007
}

\begin{abstract}
Soils and forests in the boreal region of the Northern Hemisphere are recognised as having a large capacity for storing air-borne Persistent Organic Pollutants (POPs), such as the polychlorinated biphenyls (PCBs). Following reductions of primary emissions of various legacy POPs, there is an increasing interest and debate about the relative importance of secondary re-emissions on the atmospheric levels of POPs. In spring of 2006, biomass burning emissions from agricultural fires in Eastern Europe were transported to the Zeppelin station on Svalbard, where record-high levels of many air pollutants were recorded (Stohl et al., 2007). Here we report on the extremely high concentrations of PCBs that were also measured during this period. 21 out of $32 \mathrm{PCB}$ congeners were enhanced by more than two standard deviations above the long-term mean concentrations. In July 2004, about 5.8 million hectare of boreal forest burned in North America, emitting a pollution plume which reached the Zeppelin station after a travel time of 3-4 weeks (Stohl et al., 2006). Again, 12 PCB congeners were elevated above the long-term mean by more than two standard deviations, with the less chlorinated congeners being most strongly affected. We propose that these abnormally high concentrations were caused by biomass burning emissions. Based on enhancement ratios with carbon monoxide and known emissions factors for this species, we estimate that 130 and $66 \mu \mathrm{g}$ PCBs were released per kilogram dry matter burned, respectively. To our knowledge, this is the first study relating atmospheric PCB enhancements with biomass burning. The strong effects on observed concentrations far away from the sources, suggest that biomass burning is an important source of PCBs for the atmosphere.
\end{abstract}

$\overline{\text { Correspondence to: } \mathrm{S} \text {. Eckhardt }}$ (sec@nilu.no)

\section{Introduction}

Polychlorinated biphenyls (PCBs) are intentionally produced organochlorine chemicals, assumed to have no significant natural sources (Breivik et al., 2002a). PCBs are of environmental concern because of their toxicities, persistencies, bioaccumulative properties and potential for long-range atmospheric transport (LRAT) to remote areas, such as the Arctic (e.g. AMAP, 2004). Primary emissions of PCBs into the atmosphere have been estimated to occur mainly in the industrialized regions of the middle latitudes (Breivik et al., 2007). PCBs can undergo reversible atmospheric deposition with terrestrial and aquatic environments through an exchange process commonly termed grass-hopping (Wania and Mackay, 1993). Atmospheric deposition of PCBs may furthermore be enhanced in cold environments, relative to warmer regions, through cold condensation effects (Wania and Mackay, 1993). Furthermore, fractionation of a PCB mixture on a global scale has been predicted (Wania and Mackay, 1993) and indeed observed in some studies (e.g. Agrell et al., 1999; Gioia et al., 2006), but not all (e.g. Jaward et al., 2004). For example, a study of PCBs in global surface soils observed fractionation only in the northernmost subset of samples (Meijer et al., 2003). Still, differences in key physical-chemical properties among the PCBs ( $\mathrm{Li}$ et al., 2003) are recognised among the key factors that dictate LRAT behavior (e.g. Beyer et al., 2003).

Over a prolonged time-period, these phenomena may lead to atmospheric transport from the middle latitude source regions towards the polar regions where they can accumulate and reach quite high concentrations (AMAP, 2004; Wania and Mackay, 1993). Following significant reductions in primary emissions over the last decades (Breivik et al., 2007), the relative importance of secondary re-emissions is expected to increase (Hung et al., 2005). Thus, it becomes important to investigate if there are processes that may have the potential to significantly enhance secondary re-emissions from

Published by Copernicus Publications on behalf of the European Geosciences Union. 
major environmental storage reservoirs. Around $21 \mathrm{kt}(1.6 \%$ of the cumulative production) of PCBs are stored in background soils, where the greatest reservoir is found between $45^{\circ}-60^{\circ}$ N. (Meijer et al., 2003). Levels of PCBs in forest soils are typically elevated in comparison to grassland soils, because of the forest filter effect (Horstmann and McLachlan, 1998; Wania and McLachlan, 2001). Thus, soils in the middle latitudes are playing a key role in the overall global fate of PCBs by both reducing the inflow of PCBs into the Arctic (Ockenden et al., 2003; Su and Wania, 2005) and acting as a significant reservoir of PCBs deposited in the past (Meijer et al., 2003).

Biomass burning (BB) is known to be a large source of many other air contaminants (Andreae and Merlet, 2001) and BB plumes can be transported over intercontinental (Forster et al., 2001) and even hemispheric-scale (Damoah et al., 2004) distances. It has been recognised that distinct chemical elements can be stored in the soils or biomass for a long time and, during a fire, can be re-injected into the atmosphere and subsequently transported over great distances. This has been documented, for instance, for mercury (Sigler et al., 2003), and for radioactive cesium-137, which was produced by nuclear bomb testing in the last century and is still stored in forests (Wotawa et al., 2006). However, we are not aware of a study that has documented an episode with enhanced atmospheric PCB concentrations as a result of BB. In this study, we show that PCB levels were greatly enhanced during two previously documented LRAT episodes (Stohl et al., 2006a,b), during which BB emissions were transported thousands of kilometres to a measurement station in the European Arctic.

\section{Methods}

\subsection{Sampling site and sampling method}

We present weekly measurements from the research station Zeppelin (11.9 ${ }^{\circ} \mathrm{E}, 78.9^{\circ} \mathrm{N}, 478 \mathrm{~m}$ a.s.1.) (Berg et al., 2004; $\mathrm{Su}$ et al., 2006). The station is situated in an unperturbed Arctic environment on a ridge of the Zeppelin mountain on the western coast of Spitsbergen. For sampling, a combination of glass fiber filter and two polyurethane foam (PUF) plugs $\left(25 \mathrm{~kg} / \mathrm{m}^{3}, 11 \times 5 \mathrm{~cm}\right)$ was used (e.g. Thrane and Mikalsen, 1981). The glass fiber filter was cleaned by heating to $450^{\circ}$ for $8 \mathrm{~h}$. The PUFs were pre-extracted with acetone and toluene for $8 \mathrm{~h}$ using Soxhlet extraction and then dried under vacuum. A sample volume of about $1000 \mathrm{~m}^{3}$ was taken using a high volume sampler for $48 \mathrm{~h}$. After sampling the exposed filter and PUFs were sent to the laboratory for analysis. A mix of ${ }^{13} \mathrm{C}$-isotope-labeled standards of PCBs was added to filter and PUFs and they were Soxhlet extracted using hexane/diethyl ether 9:1. After pre-concentration to $2 \mathrm{ml}$ concentrated sulphuric acid was added in order to eliminate other non-persistent components. The organic phase was then cleaned using a silica column ( $4 \mathrm{~g}$ silica) eluted with n-hexane/diethyl ether. The sample was further concentrated by applying a gentle stream of purified nitrogen. After volume reduction to approximately $0.1 \mathrm{ml}$, tetrachloronaphthalene was added as a recovery standard.

The isomer identification and quantification was done with GC/MS using a Hewlett-Packard 5890II (1990-2003) or 6890 (2003-2006) gas chromatograph coupled to an AutoSpec mass spectrometer (Micromass Waters, Manchester, UK). The high-resolution gas chromatographic conditions were as follows: separation on a $50 \mathrm{~m} \times 0.22 \mathrm{~mm}$ inner diameter fused silica capillary coated with $0.15 \mu \mathrm{m}$ of HT-8; carrier gas, He, at a flow of $35-40 \mathrm{~cm} / \mathrm{s}\left(90^{\circ} \mathrm{C}\right)$ splitless injection of $1 \mu \mathrm{L}$; splitless time $2 \mathrm{~min}$; injector temperature $280^{\circ} \mathrm{C}$; temperature program $90^{\circ} \mathrm{C}$ for $2 \mathrm{~min}$, then $25^{\circ} \mathrm{C} / \mathrm{min}$ to $170^{\circ} \mathrm{C}$, and $3^{\circ} \mathrm{C} / \mathrm{min}$ to $300^{\circ} \mathrm{C}$, finally $3 \mathrm{~min}$ isothermal. The detection and quantification was done using high resolution mass spectrometry (resolution $>10000$ ) with electron impact ionization. Two masses were monitored for each isomer group. Compounds with certified purity $(\geq 98 \%)$ were used as reference standards. A rigorous quality control concept for the determination of organic compounds in air based on the requirements in the European quality norm NS-EN ISO/IEC 17025 was applied. Before each new series of samples the blank values of the complete clean-up and quantification procedures are determined. Clean-up of samples has only started when a sufficiently low blank value was obtained (not detectable or at least 10 times lower than the lowest expected results). Criteria for quantification were: The retention of the ${ }^{12} \mathrm{C}$ compound must not be later than $3 \mathrm{~s}$ compared to the corresponding ${ }^{13} \mathrm{C}$-labeled isomer and the isotope ratio of the two monitored masses must be within $\pm 20 \%$ of the theoretical value. For quantification the signal/noise ratio must be higher than $3 / 1$ and recovery of the added ${ }^{13} \mathrm{C}$ labelled internal standards must be within 40 to $130 \%$ (trichlor PCBs 20-130\%). Table 1 gives a summary of the values of the field blanks. The field blanks for some of the heavier congeners are close to the mean measured concentrations, making measured relative enhancements during the BB episodes highly uncertain. However, this has limited consequences for this study, since the atmospheric total PCB concentrations are dominated by the lighter congeners.

\subsection{Transport model}

Simulations of atmospheric transport were made using the Lagrangian particle dispersion model FLEXPART (Stohl et al., 1998, 2005) (see http://zardoz.nilu.no/ andreas/flextra+flexpart.html). FLEXPART releases so-called tracer particles at emission sources and calculates their trajectories using the mean winds interpolated from the meteorological input fields plus random motions representing turbulence, and a deep convection scheme (Emanuel and Živković-Rothman, 1999). The model has been used for studying a number 
of intercontinental transport events of boreal forest fire emissions (Forster et al., 2001; Spichtinger et al., 2001; Damoah et al., 2004).

FLEXPART was driven with operational analyses from the European Centre for Medium-Range Weather Forecasts (ECMWF, 2002) with $1^{\circ} \times 1^{\circ}$ resolution (derived from T319 spectral truncation) and nests covering the areas of main interest with $0.36^{\circ} \times 0.36^{\circ}$ resolution. The ECMWF model versions operational in 2004 and 2005 had 60 and 91 vertical levels, respectively. In addition to the analyses at 00:00, 06:00, 12:00 and 18:00 UTC (Coordinated Universal Time), 3-h forecasts at intermediate times (03:00, 09:00, 15:00, 21:00 UTC) were used.

A special feature of FLEXPART is the possibility to run it backward in time to produce information on the spatial distribution of sources contributing to a particular measurement (Stohl et al., 2003; Seibert and Frank, 2004). Simulations with high time resolution were presented in the previous papers (Stohl et al., 2006a,b). Here, backward simulations were made for the two two-day time periods over which the samples of main interest for this study were taken. 800000 particles were released from the location of the Zeppelin station for each of the two samples. The particles were followed backward in time for 20 days for the 2006 episode and 30 days for the 2004 episode, forming what we call a retroplume, to calculate a so-called potential emission sensitivity (PES) function (Stohl et al., 2003; Seibert and Frank, 2004). The word "potential" here indicates that this sensitivity is based on transport alone, ignoring atmospheric removal processes that would reduce the sensitivity. The value of the PES function (in units of $\mathrm{sg}^{-1}$ ) in a particular grid cell is proportional to the particle residence time in that cell. It is a measure for the simulated mixing ratio at the receptor that a source of unit strength $\left(1 \mathrm{~kg} \mathrm{~s}^{-1}\right)$ in the respective grid cell would produce. Of most interest is the PES in a so-called footprint layer (0-100 $\mathrm{m}$ above ground), where we assume that surface emissions of PCBs take place. The PES map informs us about where the sampled air mass was sensitive to emission input from a possible PCB source.

\section{Description of the fire emission transport episodes}

We have clear evidence from a number of measurements and model results that the Zeppelin station was strongly influenced by BB emissions during two episodes in summer 2004 and spring 2006. These two episodes were presented in detail in two recent papers (Stohl et al., 2006a,b) and, thus, shall only be described briefly here.

\subsection{Agricultural waste burning emissions in spring 2006}

In spring 2006 smoke from agricultural fires in Eastern Europe (mostly Russia, the Baltic countries, Belorussia and the Ukraine) intruded into the European Arctic and caused the most severe air pollution episodes ever recorded there, with significant reductions in visibility (Stohl et al., 2006b). After a first short episode at the end of April, a stronger episode lasted from about 1 May until 5 May in the afternoon. Fortunately, a PCB sample was collected from 1 May at 10:14 UTC until 3 May at 08:38 UTC, a period that was heavily influenced by the $\mathrm{BB}$ emissions, except for the first few hours.

An estimate of the area burned, about 2 million hectares, and the $\mathrm{BB}$ emissions were made based on the fire detections from the MODIS instruments aboard the Aqua and Terra satellites. The transport of smoke from these fires to Svalbard as simulated by FLEXPART was confirmed by MODIS retrievals of the aerosol optical depth (AOD) and AIRS retrievals of $\mathrm{CO}$ total columns. Concentrations of certain halocarbons, carbon dioxide and $\mathrm{CO}$, as well as levoglucosan and potassium, all tracers of $\mathrm{BB}$ emissions that were measured at Zeppelin station, were used to corroborate the BB source of the pollution at Spitsbergen. The ozone and CO concentrations were the highest ever observed at the station since the measurements started in the years 1989 and 2001, respectively, and gaseous elemental mercury was also enhanced. The smoke was strongly absorbing - the aerosol light absorption coefficient was the highest ever recorded (since 2002) -, AODs were the highest ever measured at the Zeppelin station (since 1991). While most of the pollution was from BB, fossil fuel combustion also made a contribution that may have been important for some chemical species.

Figure 1 shows the footprint PES map from a retroplume simulation calculated 20 days back from the time period when the PCB sample was taken. Also shown are the locations of fires that were active on days when the retroplume passed over them. Over the two-day measurement period the transport remained confined to a relatively narrow pathway that passed exactly over the region where the fires were burning in Eastern Europe. The transport from the fire region to the station took about 3-4 days.

\subsection{Boreal forest fire emissions in summer 2004}

During summer of 2004, about 2.7 million hectare of boreal forest burned in Alaska, the by far largest annual area burned on record, and another 3.1 million hectare burned in Canada. It was shown that smoke from these fires filled large parts of the Arctic (Stohl et al., 2006a). Episodes of strongly enhanced concentrations of light absorbing aerosols were found at the stations Barrow (Alaska), Alert (Canada) and Summit (Greenland). At Zeppelin, the influence was relatively weak compared to Barrow and Summit, since the station is $4000 \mathrm{~km}$ away from where the fires burned and the air mass transport took about 3-4 weeks. Furthermore, the station was in clouds for extended periods when transport from the fires occurred, which lead to deposition of the aerosols. However, a seasonal anomaly in the $\mathrm{CO}$ concentrations at Zeppelin could be attributed unambiguously to the fire emissions. The 


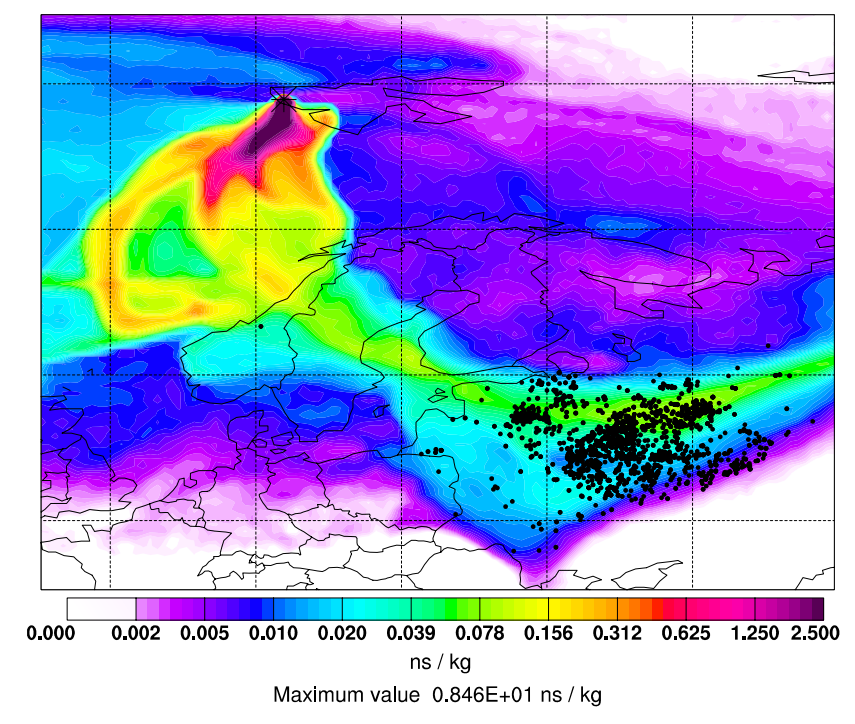

Fig. 1. Potential emission sensitivity (PES) footprint map (0$100 \mathrm{~m}$ ) for air arriving at Zeppelin between 1 May 2006 at 10:14 UTC and 3 May 2006 at 08:38 UTC 2006. Black dots show MODIS fire detections on days when the footprint emission sensitivity in the corresponding grid cell on that day exceeded $2 \mathrm{ps} \mathrm{kg}^{-1}$.

largely cloud-free period from 24-28 July stands out as having the highest values of the aerosol light absorption coefficients during the summer of 2004.

Fortunately, a PCB sample was collected from 26 July at 07:13 UTC until 28 July at 06:33 UTC, a period when both $\mathrm{CO}$ and the aerosol light absorption were strongly enhanced. Figure 2 shows the column-integrated PES map from a retroplume simulation calculated 30 days back from the time period when the fire-influenced PCB sample was taken.

Unlike in Fig. 1, the column-integrated PES is shown here because the boreal forest fires triggered substantial convection and the fire emissions sometimes reached $10 \mathrm{~km}$ and more. The plot does not show a well-defined history of the air mass but a variety of pathways but the entire retroplume remained at high northern latitudes and the PES values over anthropogenic source regions are relatively low. Because of their large emission strength and still significant emission sensitivity in the fire region, the boreal forest fire emissions contributed more to the observed $\mathrm{CO}$ increase at Zeppelin than all the anthropogenic sources combined (Stohl et al., 2006a).

\section{Results}

4.1 PCB concentrations in general and enhancements during the periods influenced by fire emissions

To get an overview of long-term mean PCB concentrations (gas+particle phase) and their variability at Zeppelin, data for 32 congeners from the period 1 January 2002 until 8
May 2006 were considered as a basis for comparison in this study. Time series of the concentrations of the seven most frequently reported PCB congeners (PCBs 28, 52, 101, 118, 138,153 and 180), as well as of the air temperature at Zeppelin are shown in Fig. 3. A box and whisker plot shows the statistics of all PCB-congeners (Fig. 4).

The hourly air temperature values were averaged over the same periods over which the PCB samples were taken. PCBs 28 and 52 have the highest average concentrations (Table 1), 2.46 and $1.12 \mathrm{pg} / \mathrm{m}^{3}$, respectively, whereas the lowest mean, $0.06 \mathrm{pg} / \mathrm{m}^{3}$, is found for PCB 180 . PCBs 28 and to some extent 52 are the only congeners investigated that are showing a systematic seasonal variation with higher values in summer. PCB 28 is highly significant correlated with temperature (correlation coefficient $-0.66, p<0.001$, Fig. 3i), but there are only moderate to low correlations for the remaining congeners. This may indicate re-volatilization of PCB 28 from the surface into the atmosphere when temperatures are high (Wania et al., 1998).

Both BB episodes (26 to 28 July 2004, 1 to 3 May 2006) clearly stand out in the time series as having some of the highest PCB concentrations of the entire record (Fig. 3). For the lighter congeners (PCBs 28 and 52), the values are the second and third highest measured but even for the heavier congeners, the values are substantially enhanced. To compare the values measured during the BB episodes to the longterm record, we calculated for every congener how many times the standard deviation they are enhanced above the long-term mean (Table 1). The forest fire episode during 2004 shows the clearest signal in the less chlorinated PCBs. For instance, for PCBs 52, 28 and 101, the values are 4.8, 4.3 and 3.4 times the standard deviation above the mean, respectively. In contrast, during the agricultural waste burning episode in 2006, the lighter as well as the heavier PCBs are significantly elevated (from 2.6 up to 6.6 times the standard deviation).

The concentrations of most congeners were strongly enhanced during the BB episodes. Of the 32 measured congeners the following eleven congeners were elevated by more than two standard deviations during both episodes: 18,28 , $31,33,47,52,66,74,99,101,149$. In 2006, in addition the following ten congeners $105,114,118,128,138,141$, $153,156,167,180$ met the criterion. PCB 37 is the only congener which was high in 2004, but not in 2006. To summarize: During the episode in 2004, 12 out of 32 congeners, had extremely high concentrations outside the normal range of variability. The lighter chlorinated PCBs (i.e. all tri-CBs and tetra-CBs as well as 2 penta-CBs) were elevated more strongly than the heavier ones. In 2006, 21 out of 32 congeners were very high, with no systematic dependence on the level of chlorination. 


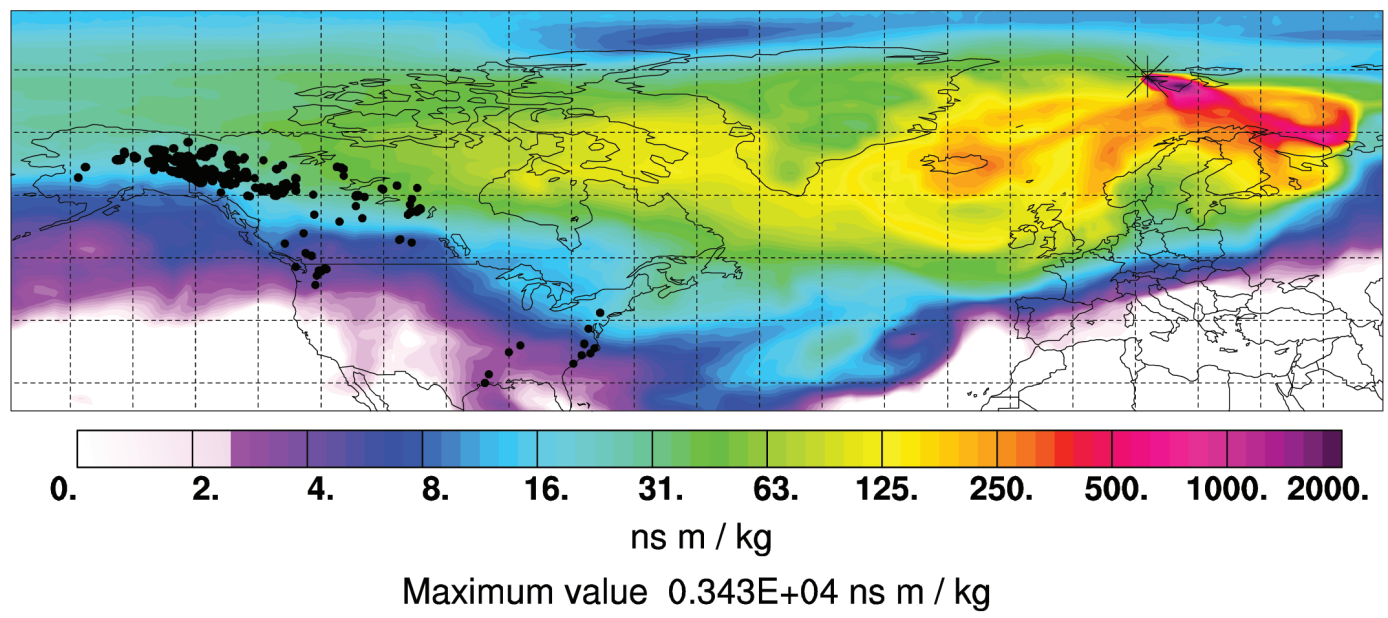

Fig. 2. Column-integrated potential emission sensitivity (PES) map for air arriving at Zeppelin between 26 July 2004 at $07: 13$ UTC and 28 July 2004 at 06:33 UTC. Black dots show MODIS fire detections on days when the column-integrated PES value in the corresponding grid cell on that day exceeded $0.5 \mathrm{~ns} \mathrm{~m} \mathrm{~kg}^{-1}$.

Table 1. The first column shows the total number of samples for the period from 1 January 2002 to 8 May 2006 . Then the average of 4 and 2 field blanks (FB) in 2004 and 2006, respectively, are reported. Mean concentrations and standard deviations ( $\mathrm{pg} \mathrm{m}^{-3}$ ) are for the whole period are listed and the values for the two samples influenced by BB emissions in 2004 and 2006 are shown separately. Furthermore, the last two columns show how many times the standard deviation the concentrations in these two samples are above the mean.

\begin{tabular}{rrrrrrrrrr}
\hline Substance & No. & FB 2004 & FB 2006 & Mean & Stdev. & Fire 2004 & Fire 2006 & $\times$ std 2004 & $\times$ std 2006 \\
\hline PCB 28 & 235 & 0.08 & 0.06 & 2.46 & 2.06 & 11.32 & 9.96 & 4.3 & 3.6 \\
PCB 52 & 229 & 0.09 & 0.07 & 1.12 & 0.56 & 3.83 & 4.11 & 4.8 & 5.3 \\
PCB 101 & 234 & 0.06 & 0.09 & 0.47 & 0.25 & 1.31 & 1.92 & 3.4 & 5.8 \\
PCB 118 & 220 & 0.03 & 0.07 & 0.19 & 0.17 & 0.37 & 1.34 & 1.1 & 6.6 \\
PCB 138 & 227 & 0.03 & 0.08 & 0.18 & 0.21 & 0.31 & 1.10 & 0.6 & 4.4 \\
PCB 153 & 231 & 0.06 & 0.16 & 0.29 & 0.37 & 0.42 & 1.64 & 0.4 & 3.7 \\
PCB 180 & 224 & 0.014 & 0.04 & 0.06 & 0.08 & 0.09 & 0.27 & 0.4 & 2.6 \\
\hline
\end{tabular}

\subsection{Could the enhancements be a temperature effect?}

It is well known, that higher temperatures trigger revolatilisation of the semivolatile PCBs and result in higher air concentrations (Wania et al., 1998). During the two BB influenced periods very high temperatures (yearly maximum in 2004 and anomalously high temperature for the season in 2006) were measured at Zeppelin. The question thus arises, whether the enhancements observed could mainly be a temperature effect, e.g. caused by volatilisation of PCBs from melting snow (Daly and Wania, 2004)? A common way to evaluate the temperature dependence of atmospheric concentrations of PCBs, is to plot the partial pressure in air versus reciprocal temperature. Studies on data at other sites almost always seem to find significant relationships, but a notable exception is Arctic sites which typically have shallow slopes or no temperature dependence (Wania et al., 1998). Indeed, a correlation could only be established for PCB 28 in our data (Fig. 3i), whereas other congeners showed a lack of correla- tion. However, it is important to note that the two samples of particular interest fall way above the regression line. Hence, the atmospheric concentrations are much higher than could be expected. Therefore it seems unlikely that these two particular episodes are better described by local re-emissions. But as detailed in the following, the observed congener patterns during the two episodes perfectly matches what could have been expected from differences in long-range atmospheric transport potentials among the PCBs during these two episodes.

\subsection{The influence of transport on congener patterns}

The environmental fate of PCBs depends on their chemical properties, which in turn is a function of their degree of chlorination. On a global scale, it has been suggested that their potential for LRAT is limited by OH-radical reaction in the case of less and intermediate chlorinated PCB congeners, whereas LRAT of the heavier congeners is limited by particle bound deposition and transfer to deep sea (Wania and 
(a) Temp

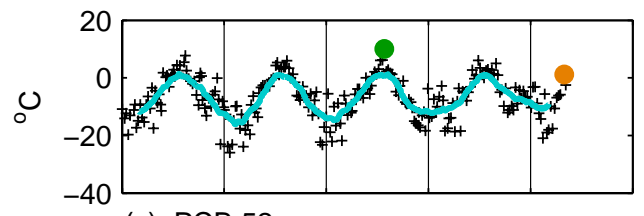

(c) PCB 52
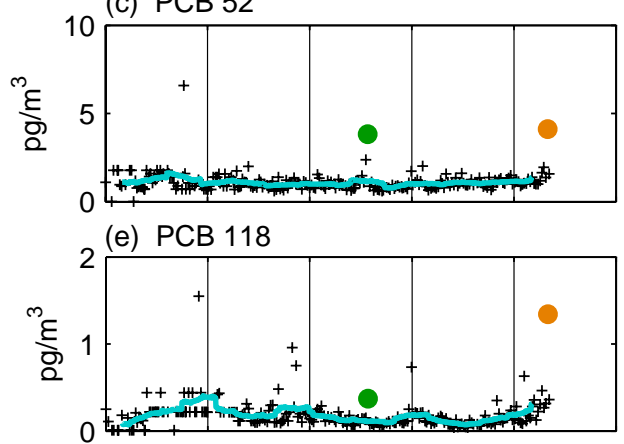

(g) PCB 153

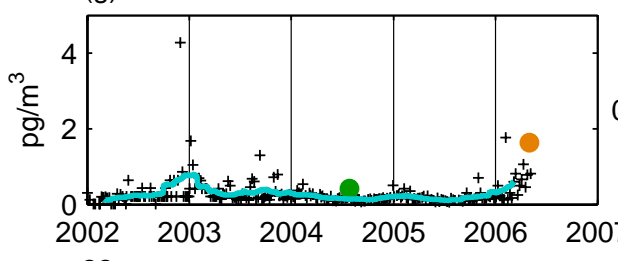

(b) PCB 28

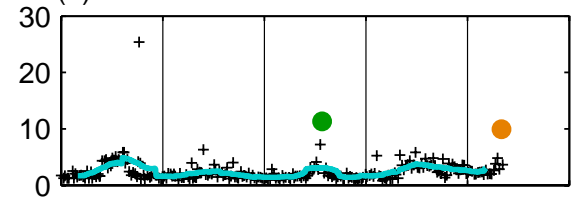

(d) PCB 101
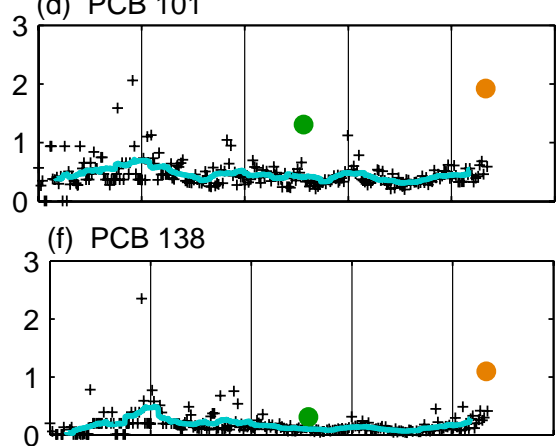

(h) PCB 180
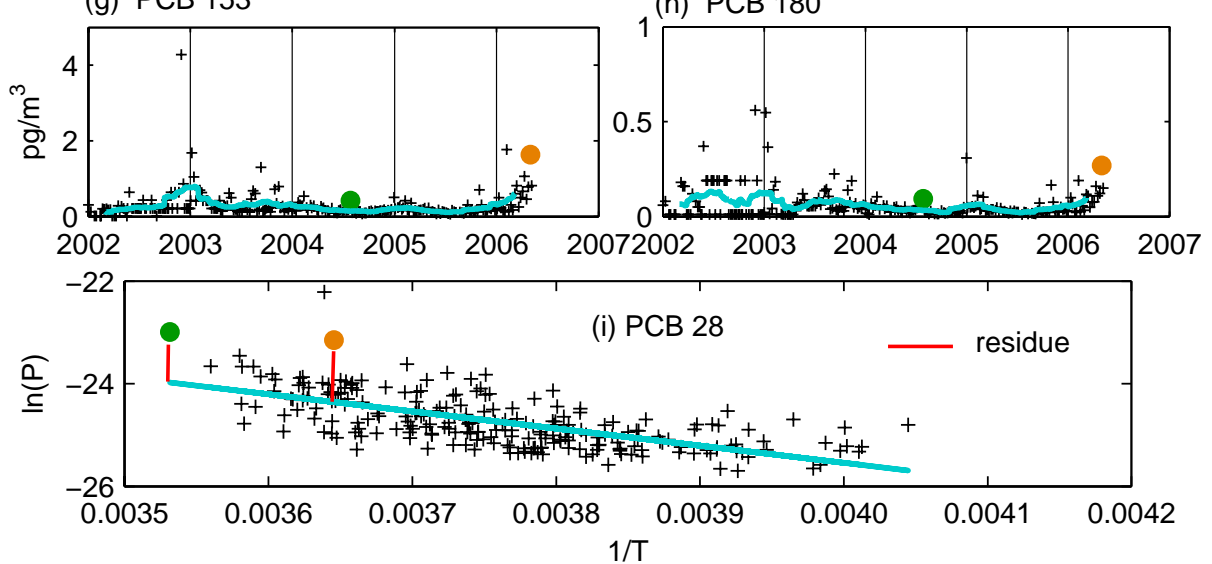

Fig. 3. Time series of temperature (a) and the seven most important PCBs (b-h) for the time period January 2002 till 8 May 2006 measured at the Zeppelin station. Crosses represent the individual concentrations, the blue line was derived by a running mean over 4 months, the green dots indicate the sample from 26 to 28 July 2004 and the orange dots the sample from 1 to 3 May 2006. Clausius-Clapeyron plot (i) relating the natural logarithm of the partial pressure $(\mathrm{Pa})$ of $\mathrm{PCB} 28$ to the inverse temperature $(\mathrm{K})$. The partial pressure is calculated as $\mathrm{P}=\log (\mathrm{PCB}$ $28 / \mathrm{mw}^{*} \mathrm{R} * \mathrm{~T}$ ), where $\mathrm{mw}$ is the molar weight of PCB 28.The red lines in (i) indicate the residuals from the regression with temperature.

Daly, 2002). However, an increased prevalence of the lighter PCBs in Arctic air following LRAT is anticipated. The concentration of $\mathrm{OH}$-radicals in the Arctic atmosphere are rather low (Leilieveld et al., 2004), further reducing the efficiencies of the removal of lighter PCBs that may be prevalent in the gaseous phase and susceptible to $\mathrm{OH}$-radical attack in this region (Anderson and Hites, 1996; Webster et al., 1998). As discussed in Sect. 3, the transport time during 2004 was several weeks compared to just a few days in 2006 . According to the method used by Wania and Daly (2002) maximum lifetimes for the PCBs in the atmosphere, assuming $\mathrm{OH}$ is the only removal mechanism were calculated. For the transport episode in spring 2006 we estimated an e-folding lifetime of PCB 52 of around 154 days. (with average $\mathrm{OH}-$ radical concentration typically for this region and season of $2.2 \mathrm{E} 5 \mathrm{~mol} / \mathrm{cm}^{3}$, transport height $1.5 \mathrm{~km},-10$ degrees). Af- ter 3 days of transport still $98 \%$ should be in the atmosphere. During July the lifetime would be 40 days, which would give $60 \%$ of the mass of PCB 52 after 20 days. (OH-radical concentration: $1.1 \mathrm{E} 6 \mathrm{~mol} / \mathrm{cm}^{3}$, transport height $4 \mathrm{~km}$, temperature -20 degrees). The relatively low concentrations of heavier PCBs during the 2004 event (Fig. 3) could thus easily be explained by differences in transport times and traveling distances. The heavier PCB congeners are increasingly sorbed to aerosols. While washout of the aerosols played a role during the episode in 2004 (Stohl et al., 2006b), extremely high aerosol concentrations were measured during the episode in 2006. Thus, favorable conditions (no rain, a short transport time) made it possible for the heavier PCBs to be transported to Zeppelin during the episode in 2006, but not in 2004. 


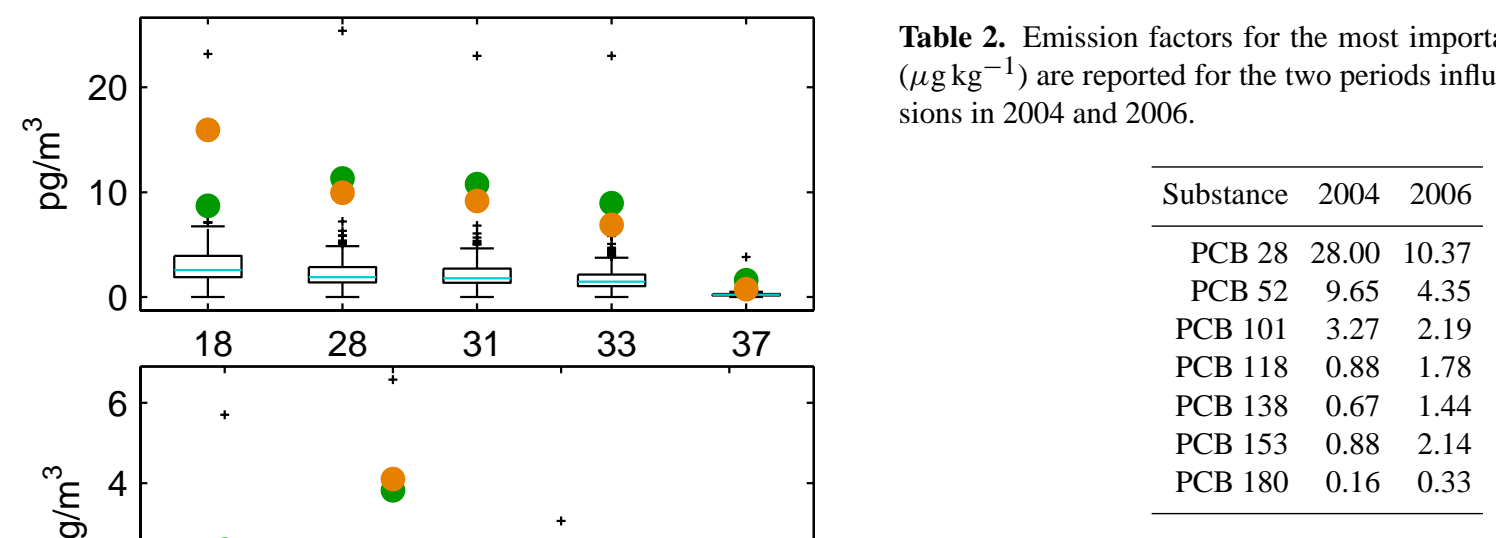

(Breivik et al., 2002a), and that the PCB soil burden is elevated in an area just north of this region (Meijer et al., 2003). The area of elevated levels in soils coincides not only with the area with highest levels of soil organic matter (Meijer et al., 2003), but also the forested regions of e.g. Siberia and Canada that are predicted to have the highest potential to scavenge PCBs from the atmosphere on a global scale (Dalla Valle et al., 2004). Revolatilization of PCBs might have occurred due to the burning of contaminated biomass, or prior/after the burning due to the enhanced temperatures in the soil, which can last for several days (Iverson and Hutchinson, 2002). Additionally it could be possible that new formation of PCBs during the biomass burning occurs. If the emission occurred during the burning itself, PCBs must survive the high temperatures of the fire. During flaming conditions, temperatures up to $1600 \mathrm{~K}$ can occur (Riggan et al., 2004). However during smoldering conditions, the temperatures are substantially lower. PCBs are broken down above temperatures of $1500 \mathrm{~K}$ (Hitchman et al., 1995), therefore we assume that a large fraction of PCBs in the biomass survived the burning.

We can use the PCB measurements to derive emission factors for the two BB events. (In this study the term "emission factor" is not used in a strict sense, because it does include revolatilization) Our approach uses the following equation:

$\mathrm{EF}_{\mathrm{PCB}}=\frac{\Delta \mathrm{C}_{\mathrm{PCB}}}{\Delta \mathrm{C}_{\mathrm{CO}}} \mathrm{EF}_{\mathrm{CO}}$

where $\Delta \mathrm{C}_{\mathrm{CO}}$ is the observed enhancement of $\mathrm{CO}$ over a background value, $\Delta \mathrm{C}_{\mathrm{PCB}}$ is the observed $\mathrm{PCB}$ enhancement, and $\mathrm{EF}_{\mathrm{CO}}$ is the emission factor of $\mathrm{CO}$. The $\mathrm{CO}$ concentration enhancements were determined subjectively by subtracting a background concentration typical for the season. For 2004 and 2006, we used CO enhancements of 27 and $62 \mu \mathrm{g} \mathrm{m}^{-3}$. For the sum of all $32 \mathrm{PCBs},-$ in order to exclude the temperature effect - we used residuals from the regression line with the temperature (see Fig. 3i for PCB 28) of 33 and $45 \mathrm{pg} \mathrm{m}^{-3}$, thus giving enhancement ratios $\Delta \mathrm{C}_{\mathrm{PCB}} / \Delta \mathrm{C}_{\mathrm{CO}}$ of $1.2 \times 10^{-6}$ and $0.7 \times 10^{-6}$, respectively. The CO emission factors for BB are relatively well known. We use average values of 107 and $92 \mathrm{~g} \mathrm{~kg}^{-1}$ dry biomass for
It has been estimated that about $86 \%$ of the historical us-
age of PCBs took place between 30 and 60 degrees North 

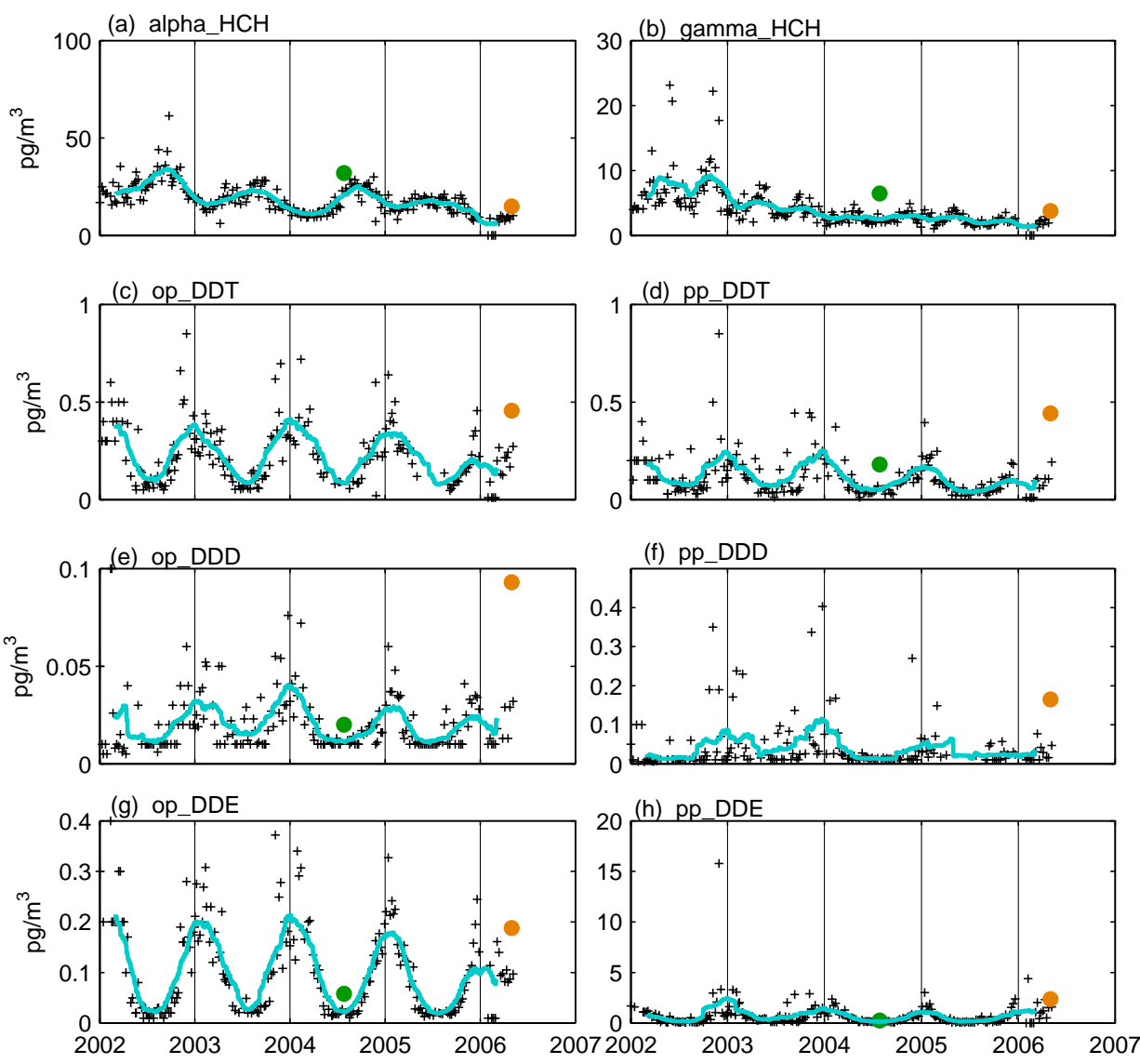

Fig. 5. Time series of $\alpha-, \gamma-\mathrm{HCH}(\mathbf{a}, \mathbf{b})$ and DDT and its' metabolites (c-h) for the time period January 2002 till 8 May 2006 measured at the Zeppelin station. Crosses represent the individual concentrations, the blue line was derived by a running mean over 4 months, the green dots indicate the sample from 26 to 28 July 2004, the orange dots indicate the sample from 1 to 3 May 2006.

the 2004 and 2006 episodes, which are typical for fires in extratropical forests and for agricultural burning, respectively (Andreae and Merlet, 2001). This finally gives PCB emission factors of 130 and $66 \mu \mathrm{g} \mathrm{kg}^{-1}$ dry matter burned. Emission factors for the seven most frequently reported PCB congeners are listed in Table 2. We estimate the uncertainty of these values to be within a factor of two to three. PCB emission factors between $0.63 \mu \mathrm{g} \mathrm{kg}^{-1}$ and $8.37 \mu \mathrm{g} \mathrm{kg}^{-1}$ were reported for oak wood burned in a wood stove (Lee et al., 2005; Gullet et al., 2003). In a forest fire simulation, where live shoot as well as litter was collected and burned gave a PCB value of $0.39 \mu \mathrm{g} \mathrm{kg}^{-1}$ (Gullett and Touati, 2003). Our emission factors for 2004 and 2006 are a factor of 16 and 8 times higher than the highest (Gullet et al., 2003) direct emission measurement and thus cannot be explained by the contents of PCBs in wood alone. However, the average surface soil concentration on a global scale has been reported to be $5.4 \mu \mathrm{g} \mathrm{kg}^{-1}$ soil (Meijer et al., 2003) furthermore being generally higher at the latitudes where the $\mathrm{BB}$ events took place. We therefore hypothesise that PCB re-volatilisation from heated soils contributes significantly to the overall $\mathrm{BB}$ emissions.

\subsection{Effect on other POPs}

The filter samples were also analysed for HCHs (hexachlorocyclohexanes), DDT and its metabolites (o, $\mathrm{p}^{\prime}$-DDT, $\mathrm{p}, \mathrm{p}^{\prime}-$ DDT, o, $\mathrm{p}^{\prime}-\mathrm{DDD}, \mathrm{p}, \mathrm{p}^{\prime}-\mathrm{DDD}$, o, $\left.\mathrm{p}^{\prime}-\mathrm{DDE}, \mathrm{p}, \mathrm{p}^{\prime}-\mathrm{DDE}\right), \mathrm{HCB}$ (hexachlorobenzene) and some other pesticides (transchlordane, cis-chlordane, trans-nonachlor, cis-nonachlor). Cis/trans-nonachlor/chlordane and HCB were not significantly enhanced during these two episodes (Fig. 5). However, the concentration of $\gamma-\mathrm{HCH}$ measured in the BB influenced sample in 2004 is the highest since January 2004 and $\alpha$-HCH lies above the average during both periods. The elevated levels of $\gamma-\mathrm{HCH}$ during 2004 could possibly be caused by transport from Canada, where lindane has been used until recent years ( $\mathrm{Li}$ et al., 2004). During the BB influenced period in $20060, p^{\prime}$-DDD, $p, p^{\prime}$-DDD and p, $\mathrm{p}^{\prime}$-DDT are clearly enhanced. Most of the DDTs and their metabolites normally have their lowest concentration in summer. The BB influenced sample in July 2004 shows enhancements, which are however below the annual average for $o, p^{\prime}$-DDD, $p, p^{\prime}$-DDT and $o, p^{\prime}$-DDE. For o, $p^{\prime}$-DDT and p, $p^{\prime}$-DDD in 2004 due to technical problems in the spectral analysis no values were 
available. No elevation in the polycyclic aromatic hydrocarbons (PAHs) could be found for 2006. This might be because of the shorter lifetime of retene compared to the PCBs (Mackay, 2001). During the episode in 2004, no PAH sample was available.

\subsection{Outlook and research needs}

For the first time, the impact of $\mathrm{BB}$ on elevated levels of PCBs in Arctic air has been documented. BB could reduce the efficiency of international agreements aiming to protect the Arctic environment (from long-range atmospheric transport) with respect to PCBs and other POPs. As primary emissions are declining and $\mathrm{BB}$ are increasing as a result of climate change, a better understanding of the releases of POPs as a result of BB becomes essential. However, many of the underlying mechanisms still require further investigation. Specifically, the release of PCBs and other POPs from soils, wood, crops and leaves/needles that are subject to fires should be quantified through further experimental work.

Acknowledgements. This study was part of the FLEXPOP project funded by the Research Council of Norway (project 171574/S30). We thank the SFT for funding the monitoring at Svalbard and C. Lunder for providing CO data. R. Lohmann and K. Jones are gratefully acknowledged for reviewing this manuscript.

Edited by: A. Petzold

\section{References}

Agrell, C., Okla, L., Larsson, P., Backe, C., and Wania, F.: Evidence of latitudinal fractionation of polychlorinated biphenyl congeners along the Baltic Sea Region, Environ. Sci. Technol., 33, 1149-1156, 1999.

Anderson, P. N. and Hites, R. A.: OH radical reactions: The major removal pathway for polychlorinated biphenyls from the atmosphere, Environ. Sci. Technol., 30, 1756-1763, 1996.

Andreae, M. O. and Merlet, P.: Emission of trace gases and aerosols from biomass burning, Global Biogeochem. Cy., 15, 955-966, 2001.

Arctic Monitoring and Assessment Programme (AMAP) AMAP Assessment 2002: Persistent Organic Pollutants in the Arctic, Oslo, Norway, 2004.

Berg, T., Kallenborn, R., and Manø, St.: Temporal trends in atmospheric heavy metal and organochlorine concentrations at Zeppelin, Svalbard, Arctic, Antarctic, and Alpine Research, 36, 283290, 2004.

Beyer, A., Wania, F., Gouin, T., Mackay, D., and Matthies, M.: Temperature dependence of the characteristic travel distance, Environ. Sci. Technol., 37, 766-771, 2003.

Breivik, K., Sweetman, A., Pacyna, J. M., Jones, K. C.: Towards a global historical emission inventory for selected PCB congeners - a mass balance approach. 1. Global production and consumption, Sci. Total Environ., 290(1-3), 181-198, 2002a.

Breivik, K., Sweetman, A., Pacyna, J. M., and Jones, K. C.: Towards a global historical emission inventory for selected PCB congeners - a mass balance approach. 2. Emissions, Sci. Total Environ., 290(1-3), 199-224, 2002b.

Breivik, K., Sweetman, A., Pacyna, J. M., and Jones, K. C.: Towards a global historical emission inventory for selected PCB congeners - a mass balance approach. 3. An update, Sci. Total Environ., 377(2-3), 311-322, 2007.

Dalla Valle, M., Dachs, J., Sweetman, A. J., and Jones, K. C.: Maximum reservoir capacity of vegetation for persistent organic pollutants: Implications for global cycling, Global Biogeochem. Cy., 18(4), GB4032, doi:10.1029/2004GB002334, 2004.

Daly, G. L. and Wania, F.: Simulating the Influence of Snow on the Fate of Organic Compounds, Environ. Sci. Technol., 38, 41764186, 2004.

Damoah, R., Spichtinger, N., Forster, C., James, P., Matthis, I., Wandinger, U., Beirle, S., and Stohl, A.: Around the world in 17 days - hemispheric-scale transport of forest fire smoke from Russia in May 2003, Atmos. Chem. Phys., 4, 1311-1321, 2004, http://www.atmos-chem-phys.net/4/1311/2004/.

White, P. W. (Ed.): IFS Documentation, ECMWF, Reading, UK, 2002.

Emanuel, K. A. and Živković-Rothman, M.: Development and evaluation of a convection scheme for use in climate models, J. Atmos. Sci., 56, 1766-1782, 1999.

Forster, C., Wandinger, U., Wotawa, G., James, P., Mattis, I., Althausen, D., Simmonds, P., O'Doherty, S., Kleefeld, C., Jennings, S. G., Schneider, J., Trickl, T., Kreipl, S., Jäger, H., and Stohl, A.: Transport of boreal forest fire emissions from Canada to Europe, J. Geophys. Res., 106, 22 887-22 906, 2001.

Gioia, R., Steinnes, E., Thomas, G. O., Meijer, S. N., and Jones, K. C.: Persistent organic pollutants in European background air: derivation of temporal and latitudinal trends, J. Environ. Monit., 8, 700-710, 2006.

Gullett, B. K. and Touati, A.: PCDD/F emissions from forest fire simulations, Environ. Sci. Technol., 37, 803-813, 2003a.

Gullett, B. K., Touati, A., and Hays, M. D.: PCDD/F, PCB, HxCBz, $\mathrm{PAH}$, and $\mathrm{PM}$ emission factors for fireplace and woodstove combustion in the San Francisco Bay region, Environ. Sci. Technol., 37, 1758-1765, 2003b.

Hitchman, M. L., Spackman, R. A., Ross, N. C., and Agra, C.: Disposal methods for chlorinated aromatic waste, Chem. Soc. Rev., 24, 423-430, 1995.

Horstmann, M. and McLachlan, M. S.: Atmospheric deposition of semivolatile organic compounds to two forest canopies, Atmos. Environ., 32, 1799-1809, 1998.

Hung, H., Lee, S. C., Wania, F., Blanchard, P., and Brice, K.: Measuring and simulating atmospheric concentration trends of polychlorinated biphenyls in the Northern Hemisphere, Atmos. Environ., 39, 6502-6512, 2005.

Iverson, L. R. and Hutchinson, T. F.: Soil temperature and moisture fluctuations during and after prescribed fire in mixed-oak forests, USA, Nat. Areas Journ., 22, 296-304, 2002.

Jaward, F. M., Barber, J. L., Booij, K., Dachs, J., Lohmann, R., and Jones, K. C.: Evidence for dynamic air-water coupling and cycling of persistent organic pollutants over the open Atlantic ocean, Environ. Sci. Technol., 38, 2617-2625, 2004.

Lee, R. G. M., Coleman, P., Jones, J. L., Jones, K. C., and Lohmann, R.: Emission Factors and Importance of PCDD/Fs, PCBs, PCNs, PAHs and $\mathrm{PM}_{10}$ from the Domestic Burning of Coal and Wood in the U.K., Environ. Sci. Technol., 39, 1436-1447, 2005. 
Lelieveld, J., Dentener, F. J., Peters, W., and Krol, C. M.: On the role of hydroxyl radicals in the self-cleansing capacity of the troposphere, Atmos. Chem. Phys., 4, 2337-2344, 2004, http://www.atmos-chem-phys.net/4/2337/2004/.

Li, N., Wania, F., Lei, Y. D., and Daly, G. L.: A comprehensive and critical compilation, evaluation, and selection of physicalchemical property data for selected polychlorinated biphenyls, J. Phys. Chem. Ref. Data, 32, 1545-1590, 2003.

Li, Y. F., Struger, J., Waite, D., and Ma, J.: Gridded Canadian lindane usage inventories with $1 / 6^{\circ} \times 1 / 4^{\circ}$ latitude and longitude resolution, Atmos. Environ., 38, 1117-1121, 2004.

Mackay, D.: Multimedia Environmental Models, The Fugacity Approach, Lewis Publishers, Florida, 2001.

Meijer, S. N., Ockenden W. A., Sweetman, A., Breivik, K., Grimalt, J. O., and Jones, K. C.: Global Distribution and Budget of PCBs and HCB in Background Surface Soils: Implications for Sources and Environmental Processes, Environ. Sci. Technol., 37, 667$672,2003$.

Ockenden, W. A., Breivik, K., Meijer S. N., Steinnes, E., Sweetman, A., and Jones, K. C.: The global re-cycling of persistent organic pollutants is strongly retarded by soils, Environ. Poll., 121, 75-60, 2003.

Riggan, P. J., Tissell, R. G., Lockwood, R. N., Brass, J. A., Pereira, J. A. R., Miranda, H. S., Miranda, A. C., Campos, T., and Higgins, R.: Remote measurement of energy and carbon flux from wildfires in Brazil, Ecol. Appl., 14, 855-872, 2004.

Seibert, P. and Frank, A.: Source-receptor matrix calculation with a Lagrangian particle dispersion model in backward mode, Atmos. Chem. Phys., 4, 51-63, 2004, http://www.atmos-chem-phys.net/4/51/2004/.

Sigler, J. M., Lee, X., and Munger W.: Emission and Long-Range Transport of Gaseous Mercury from a Large-Scale Canadian Boreal Forest Fire, Environ. Sci. Technol., 37, 4343-4347, 2003.

Spichtinger, N., Wenig, M., James, P., Wagner, T., Platt, U., and Stohl, A.: Satellite detection of a continental-scale plume of nitrogen oxides from boreal forest fires, Geophys. Res. Lett., 28, 4579-4582, 2001.

Stohl, A., Hittenberger, M., and Wotawa G.: Validation of the Lagrangian particle dispersion model FLEXPART against large scale tracer experiment data, Atmos. Environ., 32, 4245-4264, 1998.

Stohl, A., Forster, C., Eckhardt, S., Spichtinger, N., Huntrieser, H., Heland, J., Schlager, H., Wilhelm, S., Arnold, F., and Cooper, O.: A backward modeling study of intercontinental pollution transport using aircraft measurements, J. Geophys. Res., 108, 4370, doi:10.1029/2002JD002862, 2003.

Stohl, A., Forster, C., Frank, A., Seibert, P., and Wotawa, G.: Technical note: The Lagrangian particle dispersion model FLEXPART version 6.2., Atmos. Chem. Phys., 5, 2461-2474, 2005, http://www.atmos-chem-phys.net/5/2461/2005/.
Stohl, A., Andrews, E., Burkhart, J.F., Forster, C., Herber, A., Hoch, S.W., Kowal, D., Lunder, C., Mefford, T., Ogren, J.A., Sharma, S., Spichtinger, N., Stebel, K., Stone, R., Strom, J., Tørseth, K., Wehrli, C., and Yttri, K. E.: Pan-Arctic enhancements of light absorbing aerosol concentrations due to North American boreal forest fires during summer 2004, J. Geophys. Res., 111, D22214, doi:10.1029/2006JD007216, 2006a.

Stohl, A., Berg, T., Burkhart, J. F., Fjæraa, A. M., Forster, C., Herber, A., Hov, Ø., Lunder, C., McMillan, W. W., Oltmans, S., Shiobara, M., Simpson, D., Solberg, S., Stebel, K., Ström, J., Tørseth, K., Treffeisen, R., Virkkunen, K., and Yttri, K. E.: Arctic smoke - record air pollution levels in the European Arctic during a period of abnormal warmth, due to agricultural fires in Eastern Europe, Atmos. Chem. Phys., 7, 511-534, $2006 \mathrm{~b}$.

$\mathrm{Su}$, Y. and Wania, F.: Does the Forest Filter Effect Prevent Semivolatile Organic Compounds from Reaching the Arctic?, Environ. Sci. Technol., 39, 7185-7193, 2005.

Su, Y., Hung, H., Blanchard, P., Patton, G. W., Kallenborn, R., Konoplev, A., Fellin, P., Li, H., Geen, C., Stern, G., Rosenberg, B., and Barrie, L. A.: Spatial and seasonal variations of hexachlorocyclohexanes (HCHs) and hexachlorobenzene (HCB) in the Arctic atmosphere, Environ. Sci. Technol., 40, 6601-6607, 2006.

Thrane, K. E. and Mikalsen, A.: High-volume sampling of airborne polycyclic aromatic hydrocarbons using glass fiber filter and polyurethane foam, Atmos. Environ., 15, 909-918, 1981.

Wania, F. and Mackay, D.: Global fractionation and cold condensation of low volatility organochlorine compounds in polar regions, Ambio, 22, 10-18, 1993.

Wania, F. and McLachlan, M. S.: Estimating the influence of forests on the overall fate of semivolatile organic compounds using a multimedia fate model, Environ. Sci. Technol., 35, 582-590, 2001.

Wania, F. and Daly, G. L.: Estimating the contribution of degradation in air and deposition to the deep sea to the global loss of PCBs, Atmos. Environ., 36, 5581-5593, 2002.

Wania, F., Haugen, J-E, Lei, Y. D., and Mackay, D.: Temperature dependence of atmospheric concentrations of semivolatile organic compounds, Environ Sci Technol., 32, 1013-1021, 1998.

Webster, E., Mackay, D., and Wania, F.: Evaluating environmental persistence, Environ. Toxicol. Chem., 17, 2148-2158, 1998.

Wotawa, G., De Geer, L.-E., Becker, A., D’Amours, R., Jean, M., Servranckx, R., and Ungar, K.: Inter- and intra-continental transport of radioactive cesium released by boreal forest fires, Geophys. Res. Lett., 33, L12806, doi:10.1029/2006GL026206, 2006. 